know. Also, I would be delighted to hear from you any time you have questions about or suggestions for APSA.

\section{Affirmative Action Report: Women and Minorities in APSA}

\section{Michael Brintnall and Kate Petty American Political Science Association}

In recent years the Association elected its first woman president, nominated an African American president-elect, and hired a woman executive director. Assuring opportunities for women and minorities to participate in elected and appointed positions within APSA has been an important aspect of its nomination and appointment process, and current evidence shows the success of this effort. Of the 193 elected or appointed positions in APSA, 77, or $40 \%$, are held by women or minority members. By comparison, women and minorities are $24 \%$ of total Association membership, and $16 \%$ of APSA members who hold senior ranks (associate or full professor) in their institution, the group most often tapped for elected and appointed office.

Elected positions in the Association are those of officer and Council member. Appointed roles include chairing or serving on standing committees, such as the Departmental Services Committee, the Committee on Professional Ethics, Rights and Freedoms, or the PS or Teacher editorial boards; service on awards committees; and designation as a representative to other organizations, such as the American Association for the Advancement of Science (AAAS). This report looks at elected and appointed positions held by women and minorities, in comparison to membership in APSA and numbers in the profession. It also compares overall rates of participation to previous years.

\section{Participation by Women}

Women hold $36 \%$ of the total elected and appointed positions within the Association. They hold
FIGURE 1.

Positions Held by Women in APSA, by Percent of Each Group

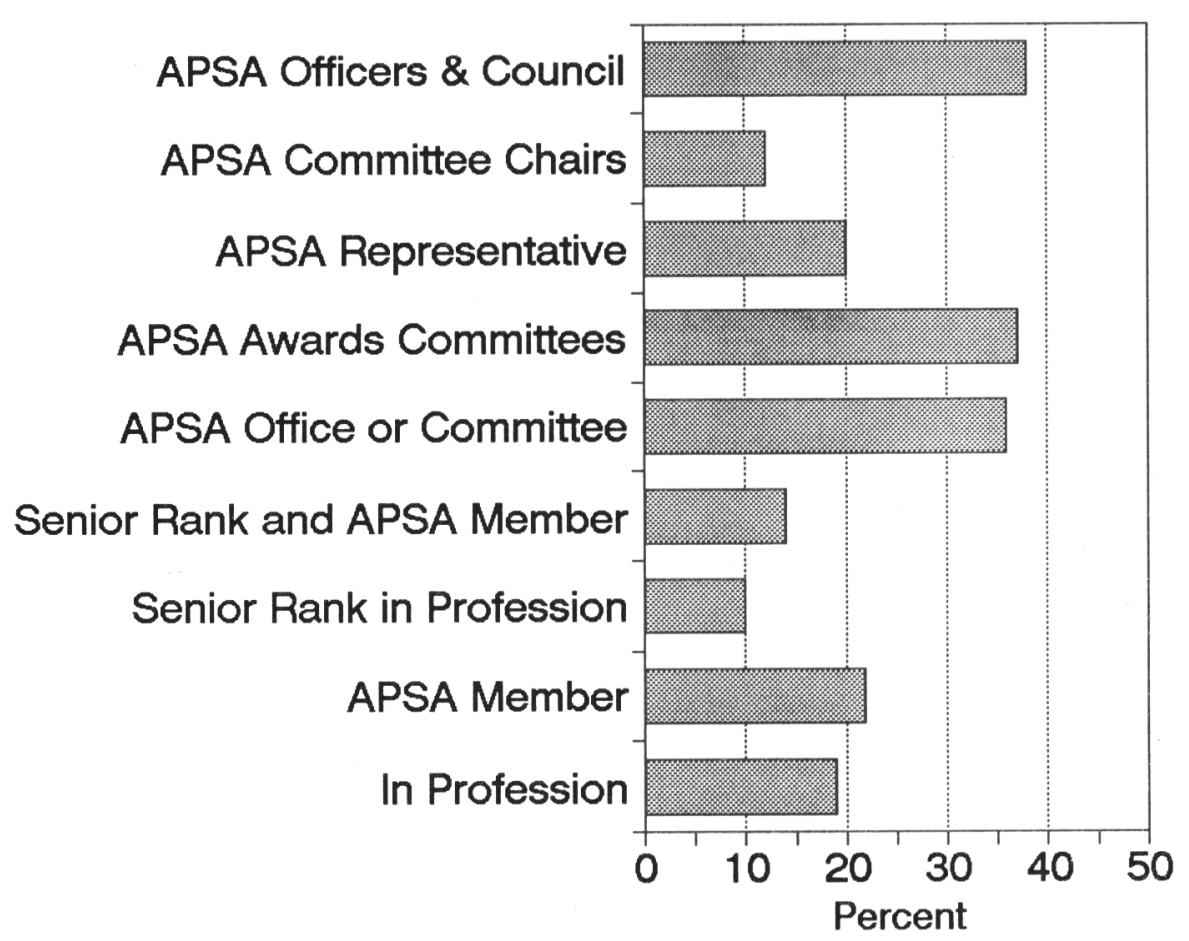

$38 \%$ of the elected posts as council members and officers, chair $12 \%$ of the standing committees, hold $37 \%$ of the positions on awards committees, and are $20 \%$ of the APSA representatives to other organizations.

By comparison, women are $22 \%$ of all APSA members, and $14 \%$ of Association members who hold senior rank. Figure 1 displays the percentages, showing participation of women in the Association, membership in the Association, and proportions in the profession as a whole. By and large, the number of women officers and committee members in APSA far exceeds their share of the membership or the professoriate, with the notable exception of appointment as committee chairs. ${ }^{1}$

\section{Minority Participation}

Minority participation in APSA elected and appointed positions also exceeds membership rates. ${ }^{2}$ Minorities hold $13 \%$ of all elected and appointed positions within the Association. Minority members fill $15 \%$ of the elected posts as council members and officers, $12 \%$ of the standing committee chairs, and $7 \%$ of seats on awards committees. No minorities serve as APSA representatives to other organizations.

Again to compare, minorities are $3 \%$ of APSA membership overall, and also of the Association membership that holds senior rank. These proportions are all shown in Figure 2 . As is the case with women, minorities' participation in leadership positions within the Association generally exceeds their representation in APSA and the professoriate.

Numbers of Asian Americans are growing in the profession and equal $4 \%$ of the political science professoriate and $3 \%$ of APSA membership. However, only one Asian American presently holds an elected or appointed office in APSA, a matter the Association may want to

\section{Conclusion}

A report in the March 1989 PS detailed participation throughout the 1980s. Throughout that decade, women and minorities held $42 \%$ of the elected and appointed offices, excluding awards committees. ${ }^{3}$ At the start of the 1990s, women and minorities made further gains, holdexplore in the future. 
FIGURE 2.

Positions Held by Minorities in APSA, by Percent of Each Group

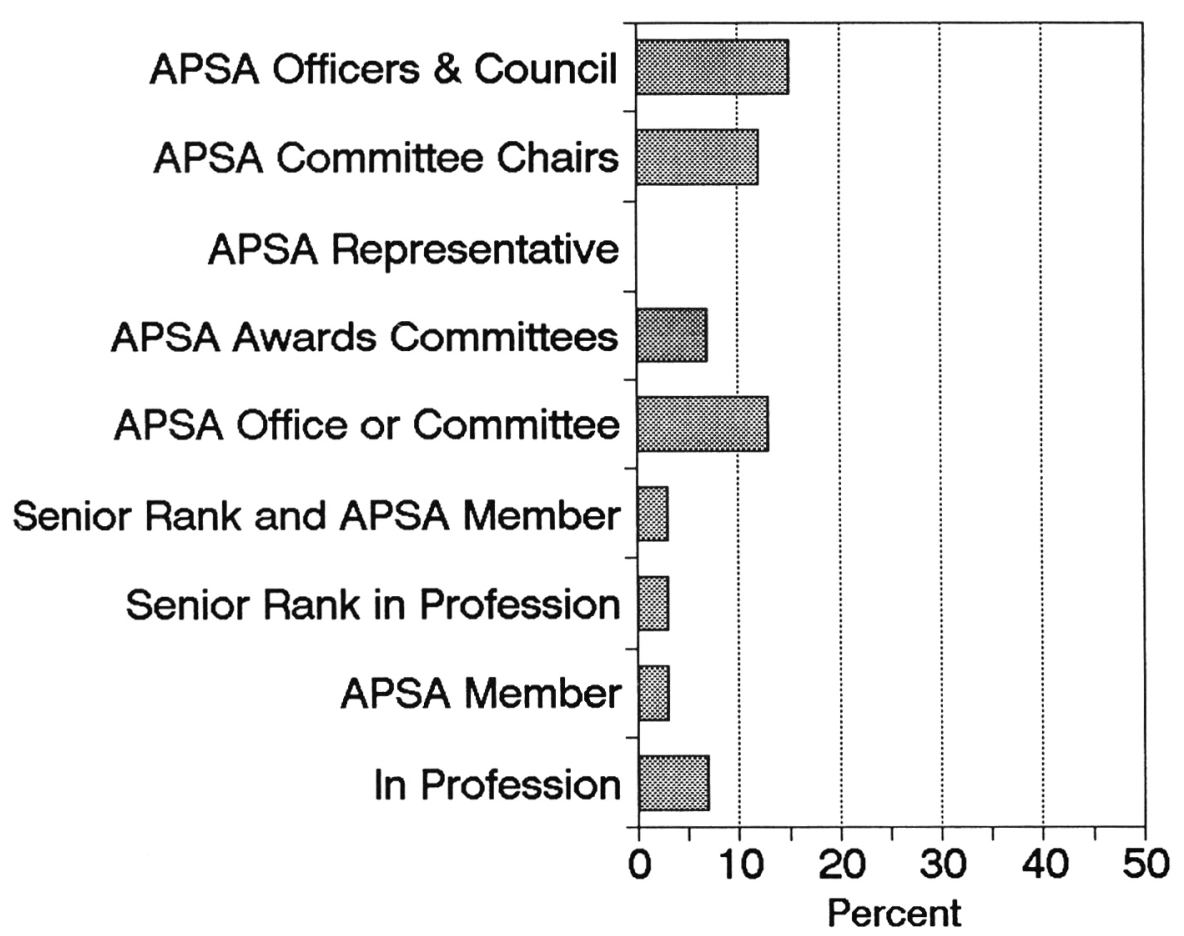

ing $46 \%$ of the comparable positions in the Association.

\section{Notes}

1. Women were also strongly represented at the Annual Meeting in 1991, serving as $24 \%$ of panel chairs and $26 \%$ of paper givers and discussants. Martin Gruberg, "Participation by Women in the 1991 APSA Meeting,", PS (December 1991), pp. 763-64.

2. African American and Latino members are included in the minority figures here. Eighty-six percent of the membership has designated race or ethnic status for the membership system. Proportions of minorities in APSA are based on this group.

3. The proportions were higher at the start of the decade, in part because the Committee on the Status of Women in the Profession initially had 10 members rather than 5; they had begun to drop toward the end of the decade, equalling $33 \%$ in 1989.

\section{APSA Minority Fellows Selected}

\section{2-93 APSA Latino Graduate Fellows}

Lisa Maria Garcia, an outstanding student attending the University of California, Berkeley, was selected as

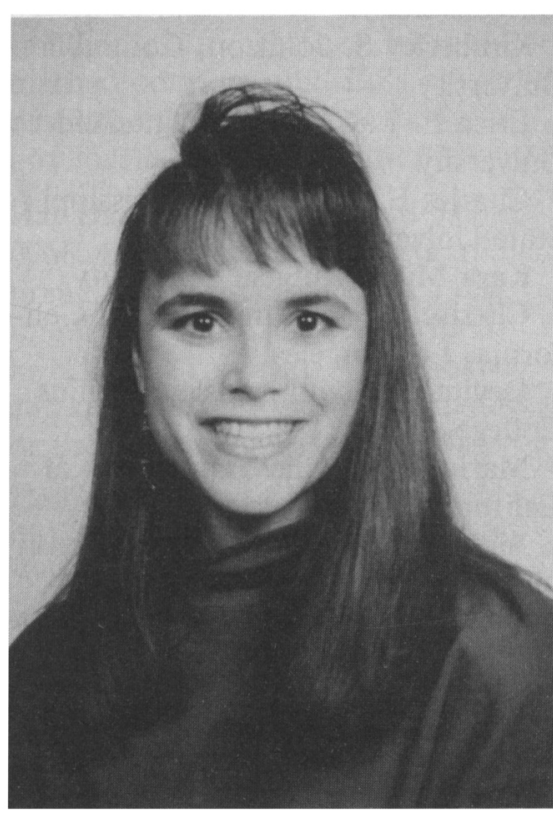

Lisa M. Garcia

the APSA's funded Latino Graduate Fellow for 1992-93.

Eleven other Latino students were selected as non-funded fellows. They are:

Linda Allegro, University of South Florida.

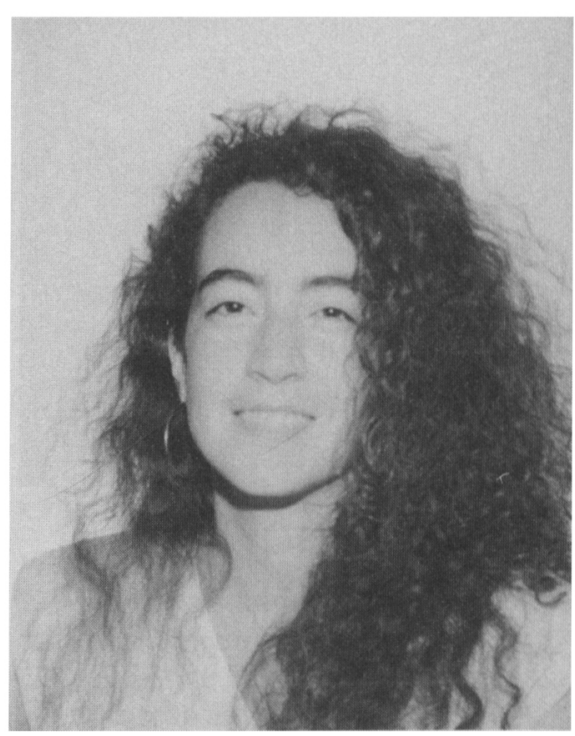

Linda Allegro

Waldemar A. Arroyo, University of Virginia.

Jorge Benitez, Harvard University.

Carlos Miguel Cordero-Cancio,

University of Puerto Rico.

Michael D. Duenes, Macalester

College.

Timothy Daniel Foley, University

of California, Santa Barbara.

Kristin M. Kuntz, Stanford

University.

David L. Leal, Stanford

University.

Dario A. Perez, Florida International University.

Sylvia Rodriguez, SUNY Binghamton.

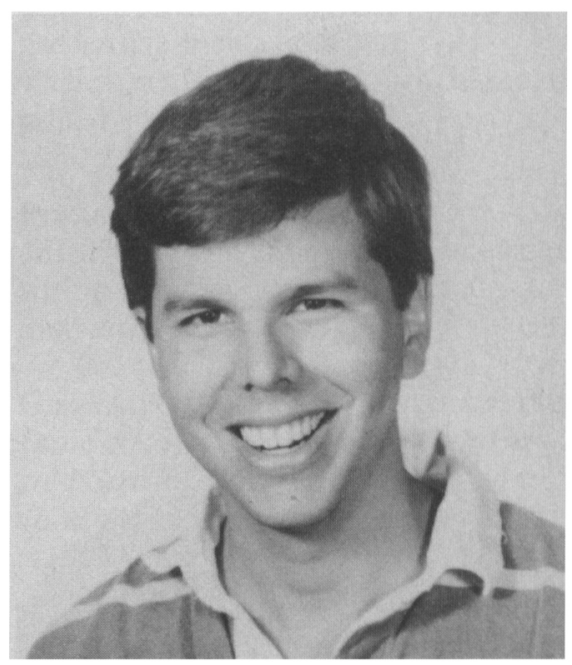

David L. Leal 